\title{
The management of cancer in the elderly: targeted therapies in
} oncology

\author{
Biagio Agostara*1, Giuseppe Carruba ${ }^{2}$ and Antonella Usset ${ }^{1}$
}

\begin{abstract}
Address: ${ }^{1}$ Clinical Oncology, Department of Oncology, "M. Ascoli" Cancer Hospital Center, ARNAS-Civico, Palermo, Italy and ${ }^{2}$ Experimental Oncology, Department of Oncology, "M. Ascoli" Cancer Hospital Center, ARNAS-Civico, Palermo, Italy

Email: Biagio Agostara* - usset.antonella@libero.it; Giuseppe Carruba - lucashbl@unipa.it; Antonella Usset - usset.antonella@libero.it

* Corresponding author
\end{abstract}

Published: 30 December 2008

Immunity \& Ageing 2008, 5:16 doi:10.1186/1742-4933-5-16

This article is available from: http://www.immunityageing.com/content/5/I/16

(C) 2008 Agostara et al; licensee BioMed Central Ltd.

This is an Open Access article distributed under the terms of the Creative Commons Attribution License (http://creativecommons.org/licenses/by/2.0), which permits unrestricted use, distribution, and reproduction in any medium, provided the original work is properly cited.
Received: 16 September 2008

Accepted: 30 December 2008

\begin{abstract}
Cancer is universally considered a disease of ageing. Today the management of elderly cancer patients poses many specific problems and it should be revisited in the light of the most recent advances in both diagnosis and treatment of human malignancies. In particular, the potential use of novel therapeutic options, based on therapeutic agents raised against molecular targets (the so called targeted therapy), appears to be promising in this clinical settings especially in view of the limited side-effects. The mainstays of cancer treatment during the twentieth century were surgery, radiation and chemotherapy. However, surgery is not curative in metastatic disease, radiation and chemotherapy are limited by side effects because they can't discriminate between healthy and cancerous cells. When key molecular changes responsible for malignant transformation were identified (e.g. growth factors and their receptors), it was hoped that new targeted agents, by inhibiting cancer-specific pathways, would spare normal cells and thereby offer improved safety benefits and a higher therapeutic index over standard chemotherapeutics. The most common targeted therapies used in clinical practice, i.e. monoclonal antibodies and small molecules, are described.
\end{abstract}

Introduction: the ageing and cancer interface Cancer is generally considered a disease of ageing, although the shared mechanisms underpinning the two processes remain unclear. Doubtlessly, incidence and mortality rates of most human cancers increase consistently with age, but they decline in the oldest old $(\geq 90$ years). This finding has been interpreted as a consequence of either the exploitation of large-scale population screening programs or the improvement of diagnostic capacities worldwide. However, there is convincing evidence that, regardless of other variables, cancer and aging remain associated until around 85 years of age, while they diverge substantially thereafter.
Recent studies have suggested that either "convergent" or "divergent" mechanisms may connect cancer and aging. In the former, molecular pathways simultaneously provide protection against cancer and resistance to ageing by limiting the generation and accumulation of cellular, genetic or epigenetic, damage. In the latter, some other pathways may eventually lead to protect from cancer but also to promote ageing, including shortening of telomeres and derepression of the INK4a/ARF locus.

It ought to be emphasized here that, by the year 2030, most patients with cancer will be aged over 65 years and many will be frail. Frailty implies a diminished physio- 
logic reserve; contributors include diminished organ function, co-morbidities, impaired physical function, and geriatric syndromes. Oncologists are challenged to appropriately identify frail elderly cancer patients aiming to select appropriate therapies that will minimize toxicity and maintain quality of life. In this framework, the advent of targeted therapies and their potential use in the elderly clinical cancer setting is awaited with hope and growing interest.

The mainstays of cancer treatment during the twentieth century were surgery, radiation and chemotherapy. However, surgery is not curative in cases of metastatic disease, and radiation and chemotherapy are limited by severe side effects and a limited capacity to discriminate between healthy and cancerous cells.

In the 1980s, several groups began to identify the key molecular changes responsible for malignant transformation. These changes included the discovery of both cancercausing oncogenes and tumor-suppressor genes that normally hold cancer in check, and the identification of epigenetic events such as promoter methylation that predispose individuals to cancer by switching genes that regulate cell growth on or off.

Cancer cells may acquire the capacity for autonomous and dysregulated proliferation through the uncontrolled production of specific molecules, generally encoded by oncogenes, that promote cell growth (growth factors) or through abnormal, enhanced expression of specific proteins (growth factor receptors) on the cell membranes to which growth factors selectively bind. Both processes trigger a series of intracellular signals that ultimately lead to the proliferation of cancer cells, induction of angiogenesis and metastasis. It was hoped that new targeted agents, by inhibiting cancer-specific pathways, would spare normal cells and thereby offer improved safety benefits over standard chemotherapeutics, while also providing a higher therapeutic index.

\section{Molecular targets and specific bullets: current clinical use and future perspectives}

The human epidermal growth factor receptor (HER) family consists in four receptor proteins, that are transmembrane tyrosine kinases and bind to specific ligands: HER1 or epidermal growth factor receptor (EGFR), HER2, HER3 and HER4.

These receptors can be inhibited by either monoclonal antibodies (e.g. trastuzumab, cetuximab), that bind to the extracellular domain of the receptor when it is in the inactive configuration, compete for the receptor binding by occluding the ligand-binding region, and thereby block ligand-induced receptor associated tyrosine kinase activa- tion, or by a tyrosine kinase inhibitor or small molecule (e.g. erlotinib, gefitinib, lapatinib), that competes with ATP to bind to the intracellular catalytic domain of receptor tyrosine kinase, thus inhibiting receptor autophosphorylation and downstream signaling.

HER2 normally regulates cell proliferation. Some tumours, in particular breast tumours, overepress HER2, a transmembrane receptor protein encoded by the protooncogene HER2/neu: infact, overexpression of HER2 (excess production of protein), amplification of the gene (excess number of copies) or both occur in approximately $20-30 \%$ of primary breast cancers, and are associated with a clinically aggressive tumour and a poor prognosis.

Overexpression of HER2 is detected by immunohistochemistry (IHC), the most frequently used method, while the amplification of the gene in the nuclei of affected cells can be detected using fluorescence in situ hybridization (FISH).

Trastuzumab was developed to target HER2: it's a recombinant, humanized IgG monoclonal antibody that selectively binds with high affinity to the extracellular domain of HER 2 and inhibits the proliferation of tumour cells that overexpress HER2. The underlying mechanism of the antitumour effects of Trastuzumab has not been fully elucidated, but it may involve a number of different actions including: a) recruiting immune cells to target tumours through antibody-dependent cellular cytotoxicity (ADCC); b) inhibiting metalloproteinase-induced cleavage of the extracellular domain of HER2, thereby preventing the formation of a truncated HER2, which is thought to have a role in the aggressiveness of breast tumours; $\mathrm{c}$ ) inhibiting HER2-mediated cellular proliferation that depends on the signaling transduction pathways P13K/ Akt and MAPK, which are activated by HER-based dimers and are essential for cellular proliferation and survival; d) inhibiting HER2-mediated neo-angiogenesis.

Additive and/or synergistic effects have been demonstrated with trastuzumab and various cytotoxic drugs (paclitaxel, docetaxel, anthracyclines, cisplatin, carboplatin, vinorelbine, capecitabine) in HER2-overexpressing breast cancer cell lines and/or human breast xenograft models. These evidences represent the rationale for the concomitant use of this monoclonal antibody and chemotherapy.

The addition of intravenous trastuzumab to first-line chemotherapy improved the time to disease progression, objective response rate, duration of response, and overall survival in randomized, multicentre trials in women with HER2-positive metastatic breast cancer [1-11]. Thus, trastuzumab has become the standard of care in this setting. 
Recent data from large phase III trials with trastuzumab in the adjuvant setting revealed significant improvements in disease-free and overall survival: trastuzumab has also become a component of adjuvant therapy for patients with HER2-positive early breast cancer [12-16]. Trastuzumab is under investigation in the neoadjuvant setting $[17,18]$.

The most common adverse events associated with trastuzumab are infusion-related symptoms, such as fever and chills, usually occurring during the infusion of the first dose; this drug is also associated with a number of serious adverse events including cardiac events, severe hypersensitivity reactions (including anaphylaxis) and pulmonary events (infiltrates, pneumonia, fibrosis, pleural effusion, acute pulmonary oedema). In particular, the risk of ventricular dysfunction and congestive heart failure is particularly increased if trastuzumab is administered in combination with anthracycline-containing chemotherapy. The mechanism involved in trastuzumab-associated cardiac events is different from that associated with anthracycline: trastuzumab can activate HER2 receptor tyrosine kinases in human myocardium, despite their low level expression, resulting in cardiomyocyte disfunction. Patients should undergo a cardiac assessment prior to beginning trastuzumab therapy and cardiac function should be monitored during trastuzumab therapy.

HER2 is also overexpressed in other malignancies, including non-small cell lung cancer, gastric cancer, pancreatic cancer, but trastuzumab, in these tumours, did not show any clinical advantage.

Cetuximab is a human-mouse chimeric monoclonal antibody (IgG1 subtype) that binds to the extracellular domain of EGFR/HER1 and block ligand binding and receptor activation. Normally, after a ligand binds to a single-chain EGFR, the receptor forms a dimer that signals within the cell by activating receptor autophosphorylation through tyrosine kinase activity. Autophosphorylation triggers a series of intracellular pathways that may result in cancer cell proliferation, blocking apoptosis, activating invasion and metastasis, and stimulating tumorinduced neovascularization. This pathway is blocked by anti-EGFR drugs.

EGFR is expressed in the majority of human epithelial cancers and was the first growth factor receptor to be proposed as a target for cancer therapy. EGFR expression is usually determined by immunohistochemical methods and was the first biomarker investigated as a potential predictor of response to anti-EGFR drugs: however, most studies have failed to show any relationship between EGFR expression and the clinical activity of these drugs. Thus, in clinical practice Cetuximab is often administered in patients affected by tumors that do not overexpress this receptor.

A multicenter, randomized phase II trial evaluating the activity of cetuximab alone or with irinotecan in patients who did not respond to irinotecan therapy showed that the combination was more effective in terms of response rate and rate of progression-free survival, while the median survival was similar with the two approaches [19]. Other studies have investigated the drug in association with oxaliplatin +/- fluoropyrimidines (CRYSTAL, EXPLORE, COIN, INT N0147) and with Bevacizumab (20, CALGB 80405) in first and second line treatment for metastatic disease.

On the basis of these results, cetuximab has been approved in combination with irinotecan for the treatment of metastatic colorectal cancer that is refractory to irinotecan-based chemotherapy.

Cetuximab is also administered in combination with radiotherapy in patients with locally advanced squamous-cell carcinoma of the head and neck: infact, in a randomized phase III trial, radiotherapy and cetuximab significantly prolonged progression-free survival, duration of locoregional control and overall survival [21]. Other trials are investigating the drug in metastatic squamous-cell carcinoma of the head and neck in combination with the standard chemotherapy, cisplatin and fluorouracil $[22,23]$. Cetuximab will be soon approved in other malignancies, in particular NSCLC [24] and pancreatic cancer.

Dose-dependent and reversible diarrhea and acneiform rashes have been the most prominent side effects, which are very similar to those associated with the use of other tyrosine kinase inhibitors: a significant positive correlation between cutaneous toxicity and rates of response, progression-free survival and overall survival has been noted in virtually all trials.

Angiogenesis is a critical step in the growth and metastatic spread of solid tumours: infact, in the absence of angiogenesis, nascent tumors remain largely dormant, with a maximum diameter of 100 to $200 \mu \mathrm{m}$, owing to limitations in the diffusion of oxygen, glucose and waste products. Vascular endothelial growth factor (VEGF) has emerged as a key mediator of tumor angiogenesis and has recently been recognized as a potential target for therapy of solid tumours. The VEGF family comprises glycoproteins designated VEGF-A, VEGF-B, VEGF-C, VEGF-D and placental growth factor (PlGF): the best characterized of the VEGF family members is VEGF-A, a homodimeric glycoprotein that is expressed in four different isoforms and binds to VEGFR1 and VEGFR2. 
Bevacizumab derives from a murine monoclonal antiVEGF antibody, which is humanized (93\% human) by incorporating murine VEGF-binding residues into human IgG framework. Bevacizumab causes inhibition of VEGFinduced proliferation, migration and survival of vascular endothelial cells and increases the permeability of these cells by preventing the binding of soluble VEGF to its receptors on the surface of endothelial cells. In addition to its direct antiangiogenetic effects, bevacizumab may also improve the delivery of chemotherapy by altering tumor vasculature, decreasing the elevated interstitial pressure in tumors and increasing the permeability of vascular endothelium.

On the basis of the results of a randomized trial demonstrating that the addition of bevacizumab to fluorouracil and leucovorin+irinotecan results in statistically significant and clinically meaningful improvement in survival among patients with previously untreated metastatic colorectal cancer [25], this drug has been approved for the treatment of these patients.

Bevacizumab is also approved in association with oxaliplatin-based regimens for first line treatment of metastatic colorectal cancer [26-28].

The drug has been approved for first line treatment of metastatic breast cancer in combination with paclitaxel [29], metastatic renal cancer in combination with interferon [30], and will be soon used for the treatment of NSCLC [31,32] and pancreatic cancer.

Potential side effects of bevacizumab include hypertension, proteinuria, bleeding and, infrequently, thrombotic events: life threatening events have occurred in a small number of patients.

The category of small molecules tyrosine kinase inhibitors includes erlotinib, lapatinib, sunitinib and sorafenib, all used in clinical practice.

Erlotinib is an oral EGFR tyrosine kinase inhibitor recently approved for the treatment of locally advanced and metastatic NSCLC patients who progress following 1 or 2 prior chemotherapy regimens. Its clinical use derives from the results of a phase III, randomized, double blind, placebo controlled study in which erlotinib increased median survival by approximately 2 months as compared with placebo. Response rates were significantly more frequent in women, in patients with adenocarcinoma, and in patients with no history of smoking: however, a significant survival advantage was observed in all patient subgroups [33].
On the basis of preclinical data demonstrating that antiEGFR drugs potentiate the antitumor activity of cytotoxic drugs, randomized trials have examined the combination of erlotinib with chemotherapy as first-line treatment for NSCLC: neither a survival advantage nor a benefit with respect to the response rate or time to progression have been seen with the addition of erlotinib to chemotherapy in any of these trials $[34,35]$.

Lapatinib is an oral ATP-competitive EGFR/HER1 and HER2 dual tyrosine kinase inhibitor: it inhibits receptor autophosphorylation and activation by binding to the ATP-binding pocket of the EGFR/HER2. In patients with HER2-positive advanced metastatic breast cancer that has progressed following treatment with previous chemotherapy regimens that included an anthracycline, a taxane, and trastuzumab, a randomized clinical trial has demonstrated that the addition of lapatinib to the chemotherapy drug capecitabine delayed the time of further cancer growth compared to capecitabine alone [36-38]. On the basis of these results, lapatinib was approved in United States in March 2007, for use in patients with advanced metastatic breast cancer in conjunction with capecitabine: it will be soon available in clinical practice also in our country.

Sunitinib and sorafenib are two orally administered multi-targeted tyrosine kinase inhibitors that have recently been approved for the treatment of metastatic renal-cell carcinoma (clear-cell histotype). Since renal-cell carcinoma is highly resistant to chemotherapy, interleukin-2 or interferon alfa were widely used as first line treatment of metastatic disease. Response rate with these cytokines were low (5 to 20\%) and median overall survival was approximately 12 months. Alternative treatments have been lacking for renal-cell carcinoma since the development of these two innovative drugs.

Sunitinib inhibits tyrosine kinase associated with VEGFR2, PDGFR $\beta$, with less potent activity against fibroblast growth factor receptor 1 (FGFR1) tyrosine kinase; sorafenib is an inhibitor of Raf-1, a member of the RAF/MEK/ ERK signaling pathway, and of tyrosine kinase associated to VEGFR1, VEGFR2, VEGFR3, PDGFR $\beta$, Flt-3 and c-KIT.

These receptor tyrosine kinases play a key role in the pathogenesis of clear-cell carcinoma, through involvement of the von Hippel-Lindau (VHL) gene, which is inactivated in up to $80 \%$ of sporadic cases of clear-cell carcinoma by deletion, mutation, or methylation. This tumor-suppressor gene encodes a protein that is involved in the regulation of the production of VEGF, PDGF and a number of other hypoxia-inducible proteins: inactivation of the VHL gene causes overexpression of these agonists of VEGFR and PDGFR and the resulting persistent stimula- 
tion of these receptors may promote tumor angiogenesis, tumor growth and metastasis. This is the rationale for the use of these small molecules in this tumor.

Sunitinib is approved for the first line treatment of metastatic clear-cell renal carcinoma after the publication of the results of a randomized phase III trial that has showed a longer progression-free survival and higher response rates, in the absence of survival benefit at the moment, in patients who received this drug than in those receiving interferon alfa [39]. Sunitinib is also approved for the second line treatment of gastrointestinal stromal tumors (GIST) [40] in progression after prior first line treatment with Imatinib [41], a multitarget tyrosine kinase inhibitor that principally blocks BCR-ABL kinase, c-kit and PDGFRassociated kinases.

Sorafenib is approved for the second line treatment of patients with metastatic clear-cell renal carcinoma in whom previous standard therapy has failed; this indication in clinical setting derives from the results of a randomized phase III trial that has showed longer progressionfree survival with sorafenib as compared with placebo [42]. Sorafenib is also administered in patients with metastatic hepatocellular carcinoma [43], on the basis of the results of a phase III, double blind, placebo-controlled trial demonstrating that median survival and time to radiologic progression were nearly 3 months longer for patients treated with sorafenib than for those given placebo.

Both sunitinib and sorafenib are under investigation in other malignancies (NSCLC, melanoma, breast cancer, thyroid carcinoma, hormone-refractory prostate cancer, etc).

The most common side effects associated with these drugs are: fatigue, rash/desquamation, hand-foot skin reactions, diarrhea, hypertension, anaemia, neutropenia, other cardiac toxicities.

The drugs reported above represent only a part of the new category of biological targeted agents: many novel drugs are under investigation and will soon help oncologists in the fight against cancer (e.g. other tyrosine kinase inhibitors-ZD6474; other monoclonal antibodies-panitumumab, matuzumab, pertuzumab; m-TOR inhibitorsTemsirolimus, Everolimus; inhibitors of $26 \mathrm{~S}$ proteosome-bortezomib; histone deacetylase inhibitors-vorinostat; metalloproteinase inhibitors-marimastat, batimastat; etc).

There is an increasing interest in the use of target therapies in patients older than 65 years, which represent the fastest growing segment of the cancer population. Concerns about cancer treatment in the elderly relate to comorbidities, which increase proportionally with age, and physiological changes associated with aging, which may influence drug metabolism and toxicity. On the basis of subgroups analysis, the major published clinical trials suggest that administration of biological agents in this class of patients is effective and safe. It would be worthwhile to design clinical trials having the elderly as target population in order to better define the clinical use of these drugs in this subset of patients.

\section{Conclusion}

Collaboration among laboratory scientists and clinical scientists hold tremendous promise. Three of the main future directions in the clinical use of target therapies are: 1) appropriate selection of patients who would benefit from treatment with these new drugs by means of molecular predictors of response; 2) determination of the most effective sequence and combination of biological drugs to use with chemotherapy, radiotherapy or both in order to optimize cytotoxicity potentiation; 3 ) introduction of biological drugs in the adjuvant setting, on the basis of the promising results obtained in the metastatic disease in order to improve outcomes; 4 ) increasing need to include the elderly population in clinical trials in order to define the possible role of biological drugs in this category of patients.

\section{Competing interests}

The authors declare that they have no competing interests.

\section{Authors' contributions}

BA, GC, and AU contributed equally to this paper. BA designed the review, GC and AU drafted the manuscript. All authors read and approved the final manuscript.

\section{Acknowledgements}

The meeting organizer Prof. C. Caruso is deeply indebted to the other speakers and chairpersons of the meeting (Frans Claas, Biagio Agostara, Marco Racchi, Giovanni Scapagnini, Daniela Mari, Vittorio Nicita-Mauro, Mario Barbagallo, Giuseppina Candore, Giuseppina Colonna-Romano, Domenico Lio) who contributed to the scientific success of the symposium. In addition, the same day of the meeting the defence of PhD thesis of students belonging to the Pathobiology PhD course directed by CC was held. Prof. Caruso is proud of the hard and challenging work of his students which motivation and enthusiasm, with the management of Drs. Giuseppina Candore, Giuseppina Colonna-Romano and Prof. Domenico Lio have permitted to the whole Immunosenescence Unit to grow in the field of immunosenescence.

\section{References}

I. Cobleigh MA, Vogel CL, Tripathy D, Robert NJ, Scholl S, Fehrenbacher L, Wolter JM, Paton V, Shak S, Lieberman G, Slamon DJ: "Multinational study of the efficacy and safety of humanized antiHER2 monoclonal antibody in women who have HER2-overexpressing metastatic breast cancer that has progressed after chemotherapy for metastatic disease". J Clin Oncol 1999, I7(9):2639-48. 
2. Slamon DJ, Leyland-Jones B, Shak S, Fuchs H, Paton V, Bajamonde A, Fleming T, Eiermann W, Wolter J, Pegram M, Baselga J, Norton L: "Use of chemotherapy plus a monoclonal antibody against HER2 for metastatic breast cancer that overexpresses HER2". N Engl J Med 200I, 344(I I):783-92.

3. Burstein HJ, Kuter I, Campos SM, Gelman RS, Tribou L, Parker LM, Manola J, Younger J, Matulonis U, Bunnell CA, Partridge AH, Richardson PG, Clarke K, Shulman LN, Winer EP: "Clinical activity of trastuzumab and vinorelbine in women with HER2-overexpressing metastatic breast cancer". J Clin Oncol 200I, 19(10):2722-30

4. Vogel CL, Cobleigh MA, Tripathy D, Gutheil JC, Harris LN, Fehrenbacher L, Slamon DJ, Murphy M, Novotny WF, Burchmore M, Shak S, Stewart SJ, Press M: "Efficacy and safety of trastuzumab as a single agent in first-line treatment of HER2-overexpressing metastatic breast cancer". J Clin Oncol 2002, 20(3):719-26.

5. Burstein HJ, Harris LN, Marcom PK, Lambert-Falls R, Havlin K, Overmoyer B, Friedlander RJ Jr, Gargiulo J, Strenger R, Vogel CL, Ryan PD, Ellis MJ, Nunes RA, Bunnell CA, Campos SM, Hallor M, Gelman R, Winer EP: "Trastuzumab and vinorelbine as first-line therapy for HER2-overexpressing metastatic breast cancer: multicenter phase II trial with clinical outcomes, analysis of serum tumor markers as predictive factors, and cardiac surveillance algorithm". J Clin Oncol 2003, 2 I ( 15):2889-95.

6. O'Shaughnessy JA, Vukelja S, Marsland T, Kimmel G, Ratnam S, Pippen JE: "Phase II study of trastuzumab plus gemcitabine in chemotherapy-pretreated patients with metastatic breast cancer". Clin Breast Cancer 2004, 5(2): 142-7.

7. Marty M, Cognetti F, Maraninchi D, Snyder R, Mauriac L, TubianaHulin M, Chan S, Grimes D, Antón A, Lluch A, Kennedy J, O'Byrne K, Conte P, Green M, Ward C, Mayne K, Extra JM: "Randomized phase II trial of the efficacy and safety of trastuzumab combined with docetaxel in patients with human epidermal growth factor receptor 2-positive metastatic breast cance administered as first-line treatment: the M7700 I study group". J Clin Oncol 2005, 23(19):4265-74.

8. Robert N, Leyland-Jones B, Asmar L, Belt R, llegbodu D, Loesch D, Raju R, Valentine E, Sayre R, Cobleigh M, Albain K, McCullough C, Fuchs L, Slamon D: "Randomized phase III study of trastuzumab, paclitaxel, and carboplatin compared with trastuzumab and paclitaxel in women with HER-2-overexpressing metastatic breast cancer". I Clin Oncol 2006, 24( I8):2786-92.

9. Schaller G, Fuchs I, Gonsch T, Weber J, Kleine-Tebbe A, Klare P, Hindenburg HJ, Lakner V, Hinke A, Bangemann N: "Phase II study of capecitabine plus trastuzumab in human epidermal growth factor receptor 2 overexpressing metastatic breast cancer pretreated with anthracyclines or taxanes". I Clin Oncol 2007, 25(22):3246-50.

10. Bartsch R, Wenzel C, Altorjai G, Pluschnig U, Rudas M, Mader RM, Gnant M, Zielinski CC, Steger GG: "Capecitabine and trastuzumab in heavily pretreated metastatic breast cancer". J Clin Oncol 2007, 25(25):3853-8.

II. Osako T, Ito Y, Takahashi S, Tokudome N, Iwase T, Hatake K: "Efficacy and safety of trastuzumab plus capecitabine in heavily pretreated patients with HER2-positive metastatic breast cancer". Cancer Chemother Pharmacol 2008, 62(I):159-64.

12. Romond EH, Perez EA, Bryant J, Suman VJ, Geyer CE Jr, Davidson NE, Tan-Chiu E, Martino S, Paik S, Kaufman PA, Swain SM, Pisansky TM, Fehrenbacher L, Kutteh LA, Vogel VG, Visscher DW, Yothers G, Jenkins RB, Brown AM, Dakhil SR, Mamounas EP, Lingle WL, Klein PM, Ingle JN, Wolmark N: "Trastuzumab plus adjuvant chemotherapy for operable HER2-positive breast cancer". N Engl J Med 2005, 353(16): 1673-84.

13. Slamon D, et al:: "Phase III randomized trial comparing doxorubicin and cyclophosphamide follone by docetaxel (ACT) with doxorubicin and cyclophosphamide follone by docetaxel and trastuzumab (ACTH) with docetaxel, carboplatin and trastuzumab (TCH) in HER2 positive early breats cancer patients: BCIRG 006 study". Breast Cancer Res and Treat 2005, 94(Suppl I):S5

14. Joensuu $\mathrm{H}$, et al.: "Trastuzumab in combination with docetaxel or vinorelbine as adjuvant treatment of breast cancer. The Finher trial". Breast Cancer Res and Treat 2005, 94(Suppl I):S5.

15. Piccart-Gebhart MJ, Procter M, Leyland-Jones B, Goldhirsch A, Untch M. Smith I, Gianni L, Baselga J, Bell R, Jackisch C, Cameron D, Dowsett M, Barrios CH, Steger G, Huang CS, Andersson M, Inbar M,
Lichinitser M, Láng I, Nitz U, Iwata H, Thomssen C, Lohrisch C, Suter TM, Rüschoff J, Suto T, Greatorex V, Ward C, Straehle C, McFadden E, Dolci MS, Gelber RD, Herceptin Adjuvant (HERA) Trial Study Team: "Trastuzumab after adjuvant chemotherapy in HER2positive breast cancer". N Engl J Med 2005, 353(16): 1659-72.

16. Smith I, Procter M, Gelber RD, Guillaume S, Feyereislova A, Dowsett M, Goldhirsch A, Untch M, Mariani G, Baselga J, Kaufmann M, Cameron D, Bell R, Bergh J, Coleman R, Wardley A, Harbeck N, Lopez RI, Mallmann P, Gelmon K, Wilcken N, Wist E, Sánchez Rovira P, PiccartGebhart MJ, HERA study team: "2-year follow-up of trastuzumab after adjuvant chemotherapy in HER2-positive breast cancer: a randomised controlled trial". Lancet 2007, 369(9555):29-36.

17. Buzdar AU, Ibrahim NK, Francis D, Booser DJ, Thomas ES, Theriault RL, Pusztai L, Green MC, Arun BK, Giordano SH, Cristofanilli M, Frye DK, Smith TL, Hunt KK, Singletary SE, Sahin AA, Ewer MS, Buchholz TA, Berry D, Hortobagyi GN: "Significantly higher pathologic complete remission rate after neoadjuvant therapy with trastuzumab, paclitaxel, and epirubicin chemotherapy: results of a randomized trial in human epidermal growth factor receptor 2-positive operable breast cancer". J Clin Oncol 2005, 23(16):3676-85

18. Buzdar AU, Valero V, Ibrahim NK, Francis D, Broglio KR, Theriault RL, Pusztai L, Green MC, Singletary SE, Hunt KK, Sahin AA, Esteva F, Symmans WF, Ewer MS, Buchholz TA, Hortobagyi GN: "Neoadjuvant therapy with paclitaxel followed by 5 -fluorouracil, epirubicin, and cyclophosphamide chemotherapy and concurrent trastuzumab in human epidermal growth factor receptor 2-positive operable breast cancer: an update of the initial randomized study population and data of additional patients treated with the same regimen". Clin Cancer Res 2007, 13(I):228-33

19. Cunningham D, Humblet $Y$, Siena S, Khayat D, Bleiberg H, Santoro A, Bets D, Mueser M, Harstrick A, Verslype C, Chau I, Van Cutsem E: "Cetuximab monotherapy and cetuximab plus irinotecan in irinotecan-refractory metastatic colorectal cancer". $N$ EnglJ Med 2004, 35 I (4):337-45.

20. Saltz LB, Lenz HJ, Kindler HL, Hochster HS, Wadler S, Hoff PM, Kemeny NE, Hollywood EM, Gonen M, Quinones M, Morse M, Chen $H X:$ "Randomized phase II trial of cetuximab, bevacizumab, and irinotecan compared with cetuximab and bevacizumab alone in irinotecan-refractory colorectal cancer: the BOND2 study". J Clin Oncol 2007, 25(29):4557-6I.

21. Bonner JA, Harari PM, Giralt J, Azarnia N, Shin DM, Cohen RB, Jones CU, Sur R, Raben D, Jassem J, Ove R, Kies MS, Baselga J, Youssoufian H, Amellal N, Rowinsky EK, Ang KK: "Radiotherapy plus cetuximab for squamous-cell carcinoma of the head and neck". N Engl J Med 2006, 354:567-78.

22. Burtness B, Goldwasser MA, Flood W, Mattar B, Forastiere AA, Eastern Cooperative Oncology Group: "Phase III randomized trial of cisplatin plus placebo compared with cisplatin plus cetuximab in metastatic/recurrent head and neck cancer: an Eastern Cooperative Oncology Group study". I Clin Oncol 2005, 23(34):8646-54. Erratum in: J Clin Oncol. 2006 Feb I;24(4):724

23. Vermorken JB: "Cetuximab extends serviva of patients with or recurrent or metastatic SCCHN when added to first line platinum-based therapy: results of a randomized phase III (EXTREME) study". 43th ASCO Annual Meeting, Chicago, June I-5 2007.

24. Rosell R, Robinet G, Szczesna A, Ramlau R, Constenla M, Mennecier BC, Pfeifer W, O'Byrne KJ, Welte T, Kolb R, Pirker R, Chemaissani A, Perol M, Ranson MR, Ellis PA, Pilz K, Reck M: "Randomized phase II study of cetuximab plus cisplatin/vinorelbine compared with cisplatin/vinorelbine alone as first-line therapy in EGFR-expressing advanced non-small-cell lung cancer". Ann Oncol 2008, 19(2):362-9.

25. Hurwitz H, Fehrenbacher L, Novotny W, Cartwright T, Hainsworth J, Heim W, Berlin J, Baron A, Griffing S, Holmgren E, Ferrara N, Fyfe $G$, Rogers B, Ross R, Kabbinavar F: "Bevacizumab plus irinotecan, fluorouracil, and leucovorin for metastatic colorectal cancer". N Engl J Med 2004, 350(23):2335-42.

26. Giantonio BJ, Catalano PJ, Meropol NJ, O'Dwyer PJ, Mitchell EP, Alberts SR, Schwartz MA, Benson $A B$ 3rd, Eastern Cooperative Oncology Group Study E3200: "Bevacizumab in combination with oxaliplatin, fluorouracil, and leucovorin (FOLFOX4) for previously treated metastatic colorectal cancer: results 
from the Eastern Cooperative Oncology Group Study E3200". J Clin Oncol 2007, 25(I 2): I539-44.

27. Hochster HS, Hart LL, Ramanathan RK, Childs BH, Hainsworth JD, Cohn AL, Wong L, Fehrenbacher L, Abubakr Y, Saif MW, Schwartzberg L, Hedrick E: "Safety and efficacy of oxaliplatin and fluoropyrimidine regimens with or without bevacizumab as firstline treatment of metastatic colorectal cancer: results of the TREE Study". J Clin Oncol 2008, 26(2I):3523-9.

28. Saltz LB, Clarke S, Díaz-Rubio E, Scheithauer W, Figer A, Wong R Koski S, Lichinitser M, Yang TS, Rivera F, Couture F, Sirzén F, Cassidy $\mathrm{J}$ : "Bevacizumab in combination with oxaliplatin-based chemotherapy as first-line therapy in metastatic colorectal cancer: a randomized phase III study". J Clin Oncol 2008, 26( I 2):20 I3-9. Erratum in: J Clin Oncol. 2008 Jun;26( I8):3 I I0

29. Miller K, Wang M, Gralow J, Dickler M, Cobleigh M, Perez EA, Shenkier T, Cella D, Davidson NE: "Paclitaxel plus bevacizumab versus paclitaxel alone for metastatic breast cancer". N Engl J Med 2007, 357(26):2666-76.

30. Escudier B, Pluzanska A, Koralewski P, Ravaud A, Bracarda S, Szczylik C, Chevreau C, Filipek M, Melichar B, Bajetta E, Gorbunova V, Bay JO, Bodrogi I, Jagiello-Gruszfeld A, Moore N, AVOREN Trial investigatore: "Bevacizumab plus interferon alfa-2a for treatment of metastatic renal cell carcinoma: a randomised, double-blind phase III trial". Lancet 2007, 370(9605):2I03-II.

31. Herbst RS, O'Neill VJ, Fehrenbacher L, Belani CP, Bonomi PD, Hart L, Melnyk O, Ramies D, Lin M, Sandler A: "Phase II study of efficacy and safety of bevacizumab in combination with chemotherapy or erlotinib compared with chemotherapy alone for treatment of recurrent or refractory non small-cell lung cancer". J Clin Oncol 2007, 25(30):4743-50.

32. Sandler A, Gray R, Perry MC, Brahmer J, Schiller JH, Dowlati A, Lilenbaum R, Johnson DH: "Paclitaxel-carboplatin alone or with bevacizumab for non-small-cell lung cancer". N Engl J Med 2006 355(24):2542-50. Erratum in: N Engl J Med. 2007 Jan 18:356(3):318

33. Shepherd FA, Rodrigues Pereira J, Ciuleanu T, Tan EH, Hirsh V, Thongprasert S, Campos D, Maoleekoonpiroj S, Smylie M, Martins R, van Kooten M, Dediu M, Findlay B, Tu D, Johnston D, Bezjak A, Clark G, Santabárbara P, Seymour L, National Cancer Institute of Canada Clinical Trials Group: "Erlotinib in previously treated nonsmall-cell lung cancer". N Engl J Med 2005, 353(2): 123-32.

34. Herbst RS, Prager D, Hermann R, Fehrenbacher L, Johnson BE, Sandler A, Kris MG, Tran HT, Klein P, Li X, Ramies D, Johnson DH, Miller VA, TRIBUTE Investigator Group: "TRIBUTE: a phase III trial of erlotinib hydrochloride (OSI-774) combined with carboplatin and paclitaxel chemotherapy in advanced non-small-cell lung cancer". J Clin Oncol 2005, 23(25):5892-9.

35. Gatzemeier U, Pluzanska A, Szczesna A, Kaukel E, Roubec J, De Rosa F, Milanowski J, Karnicka-Mlodkowski H, Pesek M, Serwatowski P, Ramlau R, Janaskova T, Vansteenkiste J, Strausz J, Manikhas GM, Von Pawel J: "Phase III study of erlotinib in combination with cisplatin and gemcitabine in advanced non-small-cell lung cancer: the Tarceva Lung Cancer Investigation Trial". J Clin Oncol 2007, 25(I 2): I545-5.

36. Burris HA 3rd, Hurwitz HI, Dees EC, Dowlati A, Blackwell KL, O'Neil B, Marcom PK, Ellis MJ, Overmoyer B, Jones SF, Harris JL, Smith DA Koch KM, Stead A, Mangum S, Spector NL: "Phase I safety, pharmacokinetics, and clinical activity study of lapatinib (GW572016), a reversible dual inhibitor of epidermal growth factor receptor tyrosine kinases, in heavily pretreated patients with metastatic carcinomas". J Clin Oncol 2005, 23(23):5305-13.

37. Geyer CE, Forster J, Lindquist D, Chan S, Romieu CG, Pienkowski T, Jagiello-Gruszfeld A, Crown J, Chan A, Kaufman B, Skarlos D, Campone M, Davidson N, Berger M, Oliva C, Rubin SD, Stein S, Cameron D: "Lapatinib plus capecitabine for HER2-positive advanced breast cancer". N Engl J Med 2006, 355(26):2733-43. Erratum in: N Engl I Med. 2007 Apr 5;356( (4):1487

38. Cameron D, Casey M, Press M, Lindquist D, Pienkowski T, Romieu CG, Chan S, Jagiello-Gruszfeld A, Kaufman B, Crown J, Chan A, Campone M, Viens P, Davidson N, Gorbounova V, Raats Il, Skarlos D, Newstat B, Roychowdhury D, Paoletti P, Oliva C, Rubin S, Stein S, Geyer CE: "A phase III randomized comparison of lapatinib plus capecitabine versus capecitabine alone in women with advanced breast cancer that has progressed on trastuzumab: updated efficacy and biomarker analyses". Breast Cance Res Treat 2008, I I 2(3):533-43.
39. Motzer RJ, Hutson TE, Tomczak P, Michaelson MD, Bukowski RM, Rixe O, Oudard S, Negrier S, Szczylik C, Kim ST, Chen I, Bycott PW, Baum CM, Figlin RA: "Sunitinib versus interferon alfa in metastatic renal-cell carcinoma". N Engl J Med 2007, 356(2): | I5-24.

40. Demetri GD, van Oosterom AT, Garrett CR, Blackstein ME, Shah MH, Verweij J, McArthur G, Judson IR, Heinrich MC, Morgan JA, Desai J, Fletcher CD, George S, Bello CL, Huang X, Baum CM, Casali PG: "Efficacy and safety of sunitinib in patients with advanced gastrointestinal stromal tumour after failure of imatinib: a randomised controlled trial". Lancet 2006, 368(9544):।329-38.

4I. Demetri GD, von Mehren M, Blanke CD, Abbeele AD Van den, Eisenberg B, Roberts PJ, Heinrich MC, Tuveson DA, Singer S, Janicek M, Fletcher JA, Silverman SG, Silberman SL, Capdeville R, Kiese B, Peng B, Dimitrijevic S, Druker BJ, Corless C, Fletcher CD, Joensuu H: "Efficacy and safety of imatinib mesylate in advanced gastrointestinal stromal tumors". N Engl J Med 2002, 347(7):472-80.

42. Escudier B, Eisen T, Stadler WM, Szczylik C, Oudard S, Siebels M, Negrier S, Chevreau C, Solska E, Desai AA, Rolland F, Demkow T, Hutson TE, Gore M, Freeman S, Schwartz B, Shan M, Simantov R, Bukowski RM, TARGET Study Group: "Sorafenib in advanced clear-cell renal-cell carcinoma". N Engl J Med 2007, 356(2): I25-34. Erratum in: N Engl J Med. 2007 Jul I2;357(2):203

43. Llovet JM, Ricci S, Mazzaferro V, Hilgard P, Gane E, Blanc JF, de Oliveira AC, Santoro A, Raoul JL, Forner A, Schwartz M, Porta C, Zeuzem S, Bolondi L, Greten TF, Galle PR, Seitz JF, Borbath I, Häussinger D, Giannaris T, Shan M, Moscovici M, Voliotis D, Bruix J, SHARP Investigators Study Group: "Sorafenib in advanced hepatocellular carcinoma". N Engl J Med 2008, 359(4):378-90.
Publish with Biomed Central and every scientist can read your work free of charge

"BioMed Central will be the most significant development for disseminating the results of biomedical research in our lifetime. "

Sir Paul Nurse, Cancer Research UK

Your research papers will be:

- available free of charge to the entire biomedical community

- peer reviewed and published immediately upon acceptance

- cited in PubMed and archived on PubMed Central

- yours - you keep the copyright
BioMedcentral 